\title{
Performance of growing/finishing pigs fed untreated or micronized hulless barley-based diets with or without $\beta$-glucanase
}

\author{
P.A. Thacker and G.L. Campbell \\ Department of Animal Science, \\ University of Saskatchewan \\ Saskatoon, Saskatchewan, S7N 5B5, Canada
}

(Received 26 November 1998; accepted 19 March 1999)

\begin{abstract}
Eighty crossbred pigs were used in a factorial design experiment to determine the effects of micronization and $\beta$-glucanase supplementation on the performance of growing-finishing pigs fed diets based on hulless barley. Micronization increased the percentage of gelatinized starch in the diets while enzyme supplementation decreased diet viscosity. Enzyme supplementation increased the digestibility coefficients for dry matter, crude protein and gross energy while micronization had no effect. Micronization also had no effect on pig growth rate. However, feed intake was slightly reduced resulting in a significant improvement in feed conversion. Enzyme supplementation had no effect on growth rate but produced a significant improvement in feed conversion during the finishing period. Neither enzyme supplementation nor micronization had any effect on carcass traits.
\end{abstract}

KEY WORDS: barley, $\beta$-glucanase, micronization, pig, digestibility, growth

\section{INTRODUCTION}

Barley is widely utilized as a feed grain in many parts of the world and forms the foundation of many rations fed to pigs (Bhatty, 1993). It is placed in the diet primarily as a source of energy, but also provides a substantial proportion of the dietary protein, vitamins and minerals required by the pig. The development of methods to improve the feeding value of barley has been the focus of a considerable amount of 
research in the past decade (Fadel et al., 1988, 1989; Graham et al., 1989; Nasi, 1992; Bosch and Verstegen, 1997; Laurinen et al., 1998).

Micronization or infrared processing is a thermal process in which grain is subjected to the application of infrared light (Lawrence, 1973a). This energy is absorbed by the product and causes constituent molecules to vibrate, resulting in rapid internal heating. The rapid internal heating affects the starch granules within the grain, causing them to swell, fracture and gelatinize (Lawrence, 1973a). The chief aim of increasing the degree of starch gelatinization is to increase the availability of starch making it more susceptible to enzymatic degradation (Holm and Bjorck, 1988; Holm et al., 1988).

Micronization has been shown to improve the digestibility of dry matter, gross energy, crude protein and amino acids (Lawrence, 1973a; Fernandes et al., 1975; Huang et al., 1998) for growing pigs fed diets containing barley, with improved performance noted in some (Lawrence, 1973b) but not all cases (Fernandes et al., 1975).

In a previous experiment, micronization of barley significantly reduced the feed intake of growing-finishing pigs leading to a significant reduction in growth rate (Thacker, 1999). The reduction in feed intake which occurred in the micronized barley-based diets was attributed to an observed increase in meal viscosity. In the rat, an increase in meal viscosity has been shown to be associated with a slow down in gastric emptying (Leeds et al., 1979), and the rate of gastric emptying is one of the main factors in the control of short term feed intake in pigs (Gregory and Rayner, 1986). Since Jensen et al. (1998) recently reported a reduction in viscosity in barley-based diets supplemented with $\beta$-glucanase, an experiment was conducted to determine the effects of $\beta$-glucanase supplementation on the performance of growing-finishing pigs fed micronized hulless barley.

\section{MATERIAL AND METHODS}

\section{Experimental animals}

Eighty crossbred pigs (Camborough, Pig Improvement Canada Ltd., Acme Alberta) weighing an average of $26.5 \pm 4.0 \mathrm{~kg}$ were assigned on the basis of sex, weight and litter to one of 4 hulless barley-based diets. Six castrates and fourteen gilts were fed each diet. The pigs were housed in groups of four in $2.7 \times 3.6 \mathrm{~m}$ concrete floored pens and were provided water ad libitum. The pens were equipped with four individual self feeders. Each pig was allowed access to its own individual feeder for 30 -min twice daily $(07.00$ and $15.00 \mathrm{~h})$. Pigs were assigned to feeders in such a way as to minimize the potential for treatment effects to be confounded with environmental effects. 
Individual body weights, feed consumptions and feed conversion were recorded weekly. The trial was run for 77 days and concluded when the pigs reached an average weight of $98.1 \pm 1.3 \mathrm{~kg}$.

\section{Experimental diets}

The experiment was conducted using a factorial design with one-half of the pigs receiving diets formulated using untreated hulless barley and the other half receiving diets in which the barley was subjected to micronization. In addition, both the untreated and micronized barley-based diets were fed either with or without enzyme.

The hulless barley was micronized using a Micro Red 20 Cereal Micronizer (InfraReady Products Limited, Saskatoon). Approximately five min prior to treatment, the raw grain was preconditioned with water to raise its moisture content to $18-20 \%$ and subsequently micronized for $50 \mathrm{sec}$ at $110^{\circ} \mathrm{C}$. The heated product was flaked using a roller mill. The flaked product was then reground ( $3 \mathrm{~mm}$ screen) prior to its incorporation in the diets.

The enzyme supplement was a commercially available product (Aspergillus niger, GNC Bioferm Inc., Saskatoon, Saskatchewan) which provided 550 units/g of $\beta$-glucanase and 800 units/g of pentosanase. The enzyme units are mg total reducing sugars (glucose equivalent) released in $10 \mathrm{~min}$ at $30^{\circ} \mathrm{C}$ and $\mathrm{pH} 4$. The final product contained dehydrated malt sprouts as a carrier and provided lessor quantities of other enzymes including cellulase, amylase, pectinase and arabinofuranosidase.

During the growing period ( 26.5 to $56.5 \mathrm{~kg}$ ), the experimental diets were formulated to supply $16.5 \%$ crude protein (Table 1) while in the finishing period $(56.5-98.1 \mathrm{~kg})$, the diets were formulated to supply approximately $14.5 \%$ crude protein (Table 2). All diets were supplemented with sufficient vitamins and minerals to meet or exceed the levels recommended by the National Research Council (1988). The diets were pelleted using low-pressure steam at approximately $60^{\circ} \mathrm{C}$.

\section{Digestibility trial}

Total tract digestibility coefficients for dry matter, crude protein and gross energy were determined using five castrates per treatment. The pigs were housed under identical conditions as those used in the growth trial and were fed the same diets as those used during the growing stage until they reached an average weight of $53.5 \mathrm{~kg}$. At this time, $0.5 \%$ chromic oxide was added to their feed as a digestibility marker. The marked feed was provided for a seven day acclimatization period, followed by a three day faecal collection. Faecal collections were made by bringing animals into a clean room immediately after feeding and recovering freshly 
TABLE 1

Formulation and chemical composition of grower pig $(26.5-56.5 \mathrm{~kg})$ diets containing either untreated or micronized hulless barley with or without cnzyme

\begin{tabular}{|c|c|c|c|c|}
\hline & \multicolumn{2}{|c|}{ Control barley } & \multicolumn{2}{|c|}{ Micronized barley } \\
\hline & - enzyme & + enzyme & - enzyme & + enzyme \\
\hline \multicolumn{5}{|l|}{ Diet formulation, $\%$ as fed } \\
\hline hulless barley $(9.9 \% \mathrm{CP})$ & 78.35 & 78.10 & 78.35 & 78.10 \\
\hline soyabean meal $(45.5 \% \mathrm{CP})$ & 18.15 & 18.15 & 18.15 & 18.15 \\
\hline dicalcium phosphate & 1.00 & 1.00 & 1.00 & 1.00 \\
\hline limestone & 1.50 & 1.50 & 1.50 & 1.50 \\
\hline salt & 0.50 & 0.50 & 0.50 & 0.50 \\
\hline vitamin-mineral premix ${ }^{1}$ & 0.50 & 0.50 & 0.50 & 0.50 \\
\hline enzyme ${ }^{2}$ & - & 0.25 & - & 0.25 \\
\hline \multicolumn{5}{|l|}{ Chemical composition, $\%$ as fed } \\
\hline moisture & 11.80 & 11.59 & 10.75 & 10.50 \\
\hline crude protein & 16.45 & 16.63 & 0.86 & 16.39 \\
\hline ash & 4.79 & 4.85 & 0.61 & 4.86 \\
\hline calcium & 0.80 & 0.90 & 2.86 & 0.82 \\
\hline phosphorus & 0.61 & 0.61 & 3.32 & 0.61 \\
\hline ether extract & 2.40 & 2.40 & 44.23 & 2.72 \\
\hline acid detergent fibre & 2.95 & 2.99 & 22.86 & 3.41 \\
\hline total starch & 49.86 & 46.18 & 51.68 & 44.47 \\
\hline gelatinized starch & 8.52 & 8.68 & 3911 & 24.84 \\
\hline percent gelatinized & 17.08 & 18.79 & 3004 & 55.85 \\
\hline gross energy, $\mathrm{kcal} / \mathrm{kg}$ & 3860 & 3866 & 1.32 & 3911 \\
\hline digestible energy, $\mathrm{kcal} / \mathrm{kg}$ & 3018 & 3274 & & 3192 \\
\hline diet viscosity $(\mathrm{cP})$ & 1.64 & 0.92 & & 0.92 \\
\hline
\end{tabular}

' supplied per kilogram of diet: 8250 IU vitamin A; 825 IU vitamin $D_{3} ; 40$ IU vitamin $E_{;} ; 4 \mathrm{mg}$ vitamin $\mathrm{K}$; $1 \mathrm{mg}$ thiamin; $5 \mathrm{mg}$ riboflavin; $35 \mathrm{mg}$ niacin; $15 \mathrm{mg}$ pantothenic acid; $2 \mathrm{mg}$ folic acid; $12.5 \mathrm{mg}$ vitamin $\mathrm{B}_{12} ; 0.2 \mathrm{mg}$ biotin; $80 \mathrm{mg}$ iron: $25 \mathrm{mg}$ manganese; $100 \mathrm{mg}$ zinc; $50 \mathrm{mg} \mathrm{Cu}$; $0.5 \mathrm{mg} \mathrm{I} ; 0.1 \mathrm{mg}$ selenium

${ }^{2}$ GNC Bioferm. Provided 550 units $\beta$-glucanase/g

voided faeces. The faecal samples were frozen for storage. Prior to analysis, the samples were dried in a forced air oven dryer at $66^{\circ} \mathrm{C}$ for $60 \mathrm{~h}$, followed by fine grinding (0.5-mm screen).

\section{Carcass measurements}

All animals were maintained on their respective diets following the conclusion of the performance trial and were slaughtered at an average weight of $105.1 \mathrm{~kg}$. Carcass weight was recorded and backfat measurements were taken at a commercial abattoir. These values were then used in calculating Carcass Value Indices 
TABLE 2

Formulation and chemical composition of finisher pig $(56.5-98.1 \mathrm{~kg})$ diets containing either untreated or micronized hulless barley with or without enzyme

\begin{tabular}{|c|c|c|c|c|}
\hline & \multicolumn{2}{|c|}{ Control barley } & \multicolumn{2}{|c|}{ Micronized barley } \\
\hline & - enzyme & + enzyme & - enzyme & + enzyme \\
\hline \multicolumn{5}{|l|}{ Diet formulation, $\%$ as fed } \\
\hline hulless barley $(9.9 \% \mathrm{CP})$ & 82.99 & 82.74 & 82.99 & 82.74 \\
\hline soyabean meal $(45.5 \% \mathrm{CP})$ & 13.81 & 13.81 & 13.81 & 13.81 \\
\hline dicalcium phosphate & 1.30 & 1.30 & 1.30 & 1.30 \\
\hline limestone & 0.90 & 0.90 & 0.90 & 0.90 \\
\hline salt & 0.50 & 0.50 & 0.50 & 0.50 \\
\hline vitamin-mineral premix ${ }^{\prime}$ & 0.50 & 0.50 & 0.50 & 0.50 \\
\hline enzyme? & - & 0.25 & - & 0.25 \\
\hline \multicolumn{5}{|l|}{ Chemical composition, $\%$ as fed } \\
\hline moisture & 12.34 & 12.21 & 12.12 & 11.42 \\
\hline crude protein & 14.85 & 15.01 & 14.81 & 14.89 \\
\hline ash & 4.15 & 4.21 & 4.17 & 4.41 \\
\hline calcium & 0.60 & 0.63 & 0.65 & 0.65 \\
\hline phosphorus & 0.60 & 0.62 & 0.62 & 0.64 \\
\hline ether extract & 2.19 & 2.32 & 2.67 & 2.57 \\
\hline acid detergent fibre & 2.91 & 3.35 & 3.36 & 3.29 \\
\hline starch & 52.56 & 53.22 & 50.69 & 50.29 \\
\hline gelatinized starch & 9.79 & 10.06 & 17.48 & 20.39 \\
\hline percent gelatinized & 18.62 & 18.90 & 34.48 & 40.54 \\
\hline diet viscosity $(\mathrm{cP})$ & 1.73 & 0.96 & 6.11 & 0.94 \\
\hline \multicolumn{5}{|c|}{$\begin{array}{l}\text { ' supplied per kilogram of diet: } 8250 \mathrm{IU} \text { vitamin } \mathrm{A} ; 825 \mathrm{IU} \text { vitamin } \mathrm{D}_{3} ; 40 \mathrm{IU} \text { vitamin } \mathrm{E} ; 4 \mathrm{mg} \text { vitamir } \\
\mathrm{K} ; 1 \mathrm{mg} \text { thiamin; } 5 \mathrm{mg} \text { riboflavin; } 35 \mathrm{mg} \text { niacin; } 15 \mathrm{mg} \text { pantothenic acid; } 2 \mathrm{mg} \text { folic acid; } 12.5 \mathrm{mg} \\
\text { vitamin } \mathrm{B}_{12} ; 0.2 \mathrm{mg} \text { biotin; } 80 \mathrm{mg} \text { iron: } 25 \mathrm{mg} \text { manganese; } 100 \mathrm{mg} \text { zinc; } 50 \mathrm{mg} \mathrm{Cu} ; 0.5 \mathrm{mg} \text { I; } 0.1 \mathrm{mg} \\
\text { selenium } \\
2 \text { GNC Bioferm. Provided } 550 \text { units } \beta \text {-glucanase } / \mathrm{g}\end{array}$} \\
\hline
\end{tabular}

according to the table of differentials in effect at the time of the experiment (Saskatchewan Pork Producers Marketing Board, 1995).

\section{Chemical analysis of diets}

Analysis of feed samples for dry matter, crude protein, acid detergent fibre, ash and ether extract were conducted according to the methods of the AOAC (1980). Starch analysis and the percentage of gelatinized starch were determined by the method of Holm et al. (1986). For the analysis of gelatinized starch, $4 \mathrm{ml}$ of deionized water was substituted for $2 \mathrm{ml} \mathrm{NaOH}$ and $2 \mathrm{ml} \mathrm{HCl}$. Diet viscosity was determined following the method of Bedford and Classen (1993). A $0.2 \mathrm{~g}$ sample was used and viscosity was determined using a Brookfield DV111 Rheometer V3.0 at a 
TABLE 3

Amino acid analysis of grower pig $(26.5-56.5 \mathrm{~kg})$ diets containing either untreated or micronized hulless barley with and without enzyme

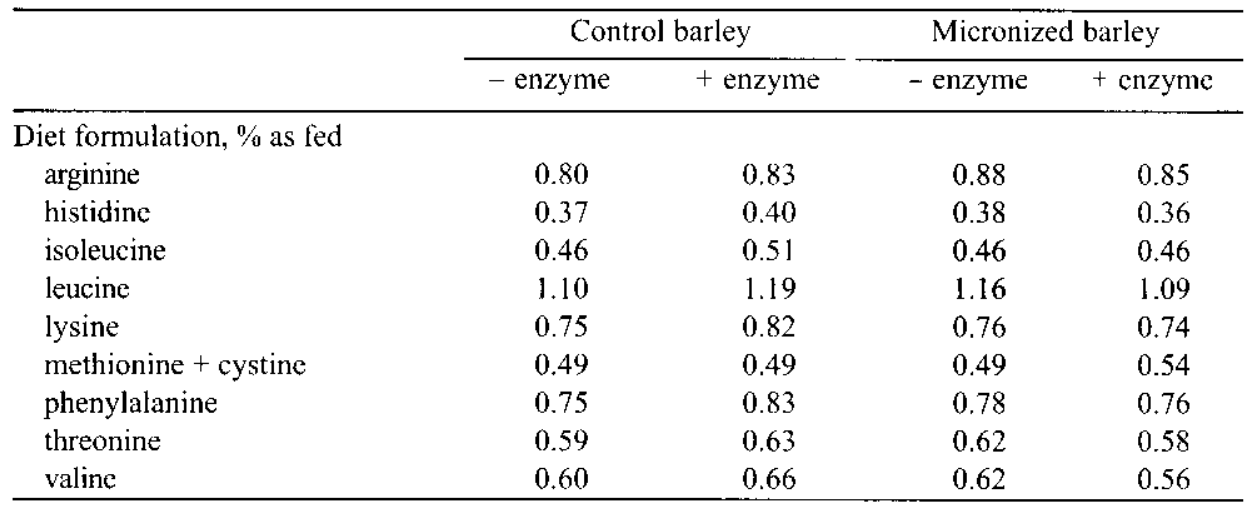

temperature of $40^{\circ} \mathrm{C}$ with the viscosity read at 12 or $40 \mathrm{rpm}$ depending on diet viscosity. An adiabatic oxygen bomb calorimeter was used to determine gross energy content. Chromic oxide was determined by the method of Fenton and Fenton (1979). An amino acid analysis of the grower diets was performed using a LKB-Biochrome 4151 Alpha Plus Amino Acid Analyzer after hydrolysis for $22 \mathrm{~h}$ with $6 \mathrm{~N}$ $\mathrm{HCl}$ (Table 3).

\section{Statistical analysis}

Pig performance data was analyzed as a factorial design using the General Linear Models procedure of the Statistical Analysis System Institute, Inc. (SAS 1985) with the factors in the model consisting of heat treatment (2), enyzme level (2), sex (2) and all two way and three way interactions. Individual feeding of animals and the distribution of treatments across pens allowed pig to be used as the replicate rather than pen. The digestibility trial was analyzed as a $2 \times 2$ factorial with the factors in the model being heat treatment (2), enzyme level (2) and their interaction.

\section{RESULTS}

Micronization increased the percentage of gelatinized starch in the grower diets from 17.9 to $53.8 \%$ while for the finisher diets, micronization increased the percentage of gelatinized starch from 18.8 to $37.5 \%$ (Tables 1 and 2 ). $\beta$-glucanase supplementation decreased viscosity for the grower diets from 1.48 to $0.92 \mathrm{cP}$, while for the finisher diets, viscosity declined from 3.92 to $0.95 \mathrm{cP}$. The digestible 
TABLE 4

Main effect means for the effect of micronization and enzyme supplementation on digestibility coefficients for dry matter, crude protein and gross energy for castrate pigs fed hulless barley-based diets

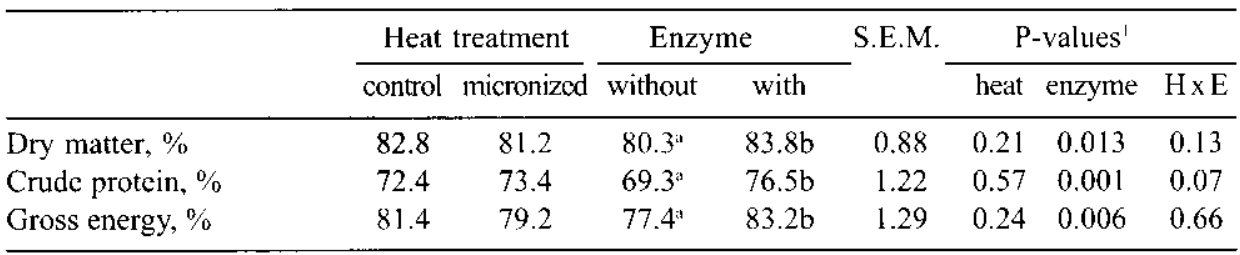

a within main effect, means followed by different letters are significantly different at the $P$ values indicated

${ }^{1} \mathrm{H}=$ heat; $\mathrm{E}=$ enzyme

TABLE 5

Interaction means for the effect of micronization and enzyme supplementation on digestibility cocfficients for dry matter, crude protein and gross energy for castrate pigs fed hulless barley-based diets

\begin{tabular}{|c|c|c|c|c|c|c|c|c|}
\hline & \multicolumn{2}{|c|}{ Control barley } & \multicolumn{2}{|c|}{ Micronized barley } & \multirow{2}{*}{ S.E.M. } & \multicolumn{3}{|c|}{ P-values' } \\
\hline & - enzym & enzyme & - enzym & + enzyme & & heat & enzyme & $\mathrm{H} \times \mathrm{E}$ \\
\hline Dry matter, $\%$ & 80.1 & 85.6 & 80.5 & 82.0 & 0.88 & 0.21 & 0.013 & 0.13 \\
\hline Crude protein, $\%$ & 67.2 & 77.6 & 71.5 & 75.3 & 1.22 & 0.57 & 0.001 & 0.07 \\
\hline Gross energy, $\%$ & 78.2 & 84.7 & 76.8 & 81.6 & 1.29 & 0.24 & 0.006 & 0.66 \\
\hline
\end{tabular}

' $\mathrm{H}=$ heat; $\mathrm{E}=$ enzyme

energy content of the grower diets increased from 3011 to $3233 \mathrm{kcal} / \mathrm{kg}$ as a result of $\beta$-glucanase supplementation.

Micronization had no significant effect on digestibility coefficients for any of the nutrients measured (Tables 4 and 5). Supplementation with $\beta$-glucanase increased the digestibility coefficient for dry matter by $4.2 \%(\mathrm{P}=0.013)$, crude protein by $9.4 \%(\mathrm{P}=0.001)$ and gross energy by $7.0 \%(\mathrm{P}=0.006)$.

During both the grower and finisher periods, micronization of barley had no effect on pig growth rate (Tables 6 and 7). Feed intake was slightly reduced in both periods resulting in a significant improvement in feed conversion during both the grower $(\mathrm{P}=0.005)$ and finisher $(\mathrm{P}=0.03)$ periods as well as over the entire experiment $(\mathrm{P}=0.002)$.

Enzyme supplementation had no significant effect on growth rate during any time period. Feed intake was slightly $(\mathrm{P}>0.05)$ reduced during all time periods producing a significant $(\mathrm{P}=0.01)$ improvement in feed efficiency during the finishing period but over the entire experimental period, no significant improvement was noted. Neither enzyme supplementation nor micronization had any effect on carcass traits (Tables 8 and 9). 
Main effect means for the effects of micronization and enzyme supplementation on the performance of pigs fed hulless barley-based diets

TABLE 6

Main effect means for the effects of micronization and enzyme supple

$\frac{\text { Heat treatment }}{\text { control micronized }} \frac{\text { Enzyme }}{\text { without with }} \frac{\text { Sex }}{\text { castrates gilts }}$
S.E.M..

\begin{tabular}{cc} 
P-Values \\
\hline heat enzyme sex
\end{tabular}

Grower period $(26.5-56.5 \mathrm{~kg})$ daily gain, $\mathrm{kg}$ daily feed, $\mathrm{kg}$ 0.87

feed conversion

1.94

0.85

$0.87 \quad 0.86$

$0.88^{\mathrm{a}}$

$0.84^{b}$

$\begin{array}{lll}1.84 & 1.89 & 1.88\end{array}$

0.84
1.87

$\begin{array}{ll}1.90 & 1.87 \\ 2.17 & 2.22\end{array}$

0.018

0.041

0.87

0.13

0.021

Finisher period (56.5-98.1 kg)

$\begin{array}{lllllllllll}\text { daily gain, } \mathrm{kg} & 1.00 & 0.99 & 1.00 & 0.99 & 1.00 & 0.99 & 0.019 & 0.91 & 0.75 & 0.90 \\ \text { daily feed, } \mathrm{kg} & 2.84 & 2.67 & 2.80 & 2.72 & 2.84^{\mathrm{a}} & 2.67^{\mathrm{b}} & 0.049 & 0.15 & 0.08 & 0.03 \\ \text { feed conversion } & 2.84^{\mathrm{a}} & 2.71^{\mathrm{b}} & 2.80^{\mathrm{a}} & 2.74^{\mathrm{b}} & 2.86^{\mathrm{a}} & 2.69^{\mathrm{b}} & 0.028 & 0.03 & 0.01 & 0.001\end{array}$

Total experiment (26.5-98.1 kg)

\begin{tabular}{lllllllllll} 
daily gain, $\mathrm{kg}$ & 0.94 & 0.93 & 0.94 & 0.93 & 0.94 & 0.93 & 0.018 & 0.91 & 0.30 & 0.58 \\
daily feed, $\mathrm{kg}$ & 2.43 & 2.29 & 2.39 & 2.34 & 2.42 & 2.30 & 0.042 & 0.22 & 0.08 & 0.12 \\
feed conversion & $2.58^{\mathrm{a}}$ & $2.48^{\mathrm{b}}$ & 2.54 & 2.51 & $2.57^{\mathrm{a}}$ & $2.49^{\mathrm{b}}$ & 0.017 & 0.002 & 0.10 & 0.01 \\
\hline
\end{tabular}

within main effect, means followed by different letters are significantly different at the $\mathrm{P}$ values indicated 
TABLE 7 Interaction means for the effects of micronization and enzyme supplementation on the performance of pigs fed hulless barley-based diets

\begin{tabular}{|c|c|c|c|c|c|c|c|c|}
\hline & \multicolumn{2}{|c|}{ Control barley } & \multicolumn{2}{|c|}{ Micronized barley } & \multirow{2}{*}{ S.E.M. } & \multicolumn{3}{|c|}{ P-values' } \\
\hline & - enzyme & t enzyme & - enzyme & enzyme & & $\mathrm{H} \times \mathrm{E}$ & $\mathrm{H} \times \mathrm{S}$ & $\mathrm{ExS}$ \\
\hline \multicolumn{9}{|c|}{ Grower period $(26.5-56.5 \mathrm{~kg})$} \\
\hline daily gain, $\mathrm{kg}$ & 0.86 & 0.87 & 0.87 & 0.84 & 0.018 & 0.51 & 0.01 & 0.21 \\
\hline daily feed, $\mathrm{kg}$ & 1.92 & 1.96 & 1.87 & 1.81 & 0.041 & 0.57 & 0.05 & 0.01 \\
\hline feed conversion & 2.22 & 2.25 & 2.15 & 2.17 & 0.016 & 0.80 & 0.55 & 0.67 \\
\hline \multicolumn{9}{|c|}{ Finisher period $(56.5-98.1 \mathrm{~kg})$} \\
\hline daily gain, $\mathrm{kg}$ & 1.00 & 1.00 & 1.00 & 0.98 & 0.019 & 0.99 & 0.35 & 0.84 \\
\hline daily feed, $\mathrm{kg}$ & 2.85 & 2.84 & 2.75 & 2.60 & 0.049 & 0.74 & 0.09 & 0.27 \\
\hline feed conversion & 2.85 & 2.83 & 2.77 & 2.65 & 0.028 & 0.59 & 0.23 & 0.13 \\
\hline \multicolumn{9}{|c|}{ Total experiment $(26.5-98.1 \mathrm{~kg})$} \\
\hline daily gain, $\mathrm{kg}$ & 0.94 & 0.94 & 0.94 & 0.92 & 0.018 & 0.82 & 0.20 & 0.21 \\
\hline daily feed, $\mathrm{kg}$ & 2.42 & 2.43 & 2.35 & 2.24 & 0.042 & 0.69 & 0.06 & 0.09 \\
\hline feed conversion & 2.58 & 2.58 & 2.51 & 2.45 & 0.017 & 0.70 & 0.20 & 0.38 \\
\hline
\end{tabular}

' $\mathrm{H}=$ heat; $\mathrm{E}=$ enzyme; $\mathrm{S}=\operatorname{sex}$

During the grower period, castrates gained significantly faster than gilts $(\mathrm{P}=0.021)$ while in the the finisher period, castrates consumed significantly more feed $(\mathrm{P}=0.03)$ but had a poorer feed efficiency $(\mathrm{P}=0.001)$ than gilts (Tables 6 and 7$)$. Gilts had a better feed efficiency than castrates during the entire experimental period ( $\mathrm{P}=0.01)$. Carcasses obtained from gilts had a higher carcass value index $(P=0.001)$, higher yield class $(P=0.001)$, lower backfat $(P=0.001)$ and higher carcass lean $(\mathrm{P}=0.001)$ than carcasses from castrates (Tables 8 and 9).

\section{DISCUSSION}

Micronization increased the percentage of gelatinized starch in both the grower and finisher diets. Gelatinization is defined as ,the irreversible destruction of the crystalline order in a starch granule so that the surface of every molecule is made accessible to solvents or reactants" (Hauck et al., 1994). The destruction of the ordered crystalline structures within a starch granule has been suggested to increase the susceptibility of starch to breakdown by amylase (Holm and Bjorck, 1988). Thermal processing has also been shown to result in extensive expansion and destruction of cell walls and protein structures encapsulating the starch which further increases its susceptibility to enzymatic attack (Holm et al., 1989).

Based on the above, it was expected that micronization would have a positive effect on nutrient digestibility. However, in the present experiment, micronization 
Main effect means for the effects of micronization and enzyme supplementation on carcass traits of pigs fed hulless barley-based diets

TABLE 8

\begin{tabular}{|c|c|c|c|c|c|c|c|c|c|c|}
\hline & \multicolumn{2}{|c|}{ Heat treatment } & \multicolumn{2}{|c|}{ Enzyme } & \multicolumn{2}{|c|}{ Sex } & \multirow[t]{2}{*}{ S.E.M.. } & \multicolumn{3}{|c|}{ P-Values } \\
\hline & control & micronized & without & with & castrates & gilts & & heat & enzyme & sex \\
\hline Slaughter weight, $\mathrm{kg}$ & 105.0 & 103.8 & 104.7 & 104.1 & $102.8^{a}$ & $106.0^{\mathrm{b}}$ & 1.10 & 0.368 & 0.473 & 0.010 \\
\hline Hot carcass weight, $\mathrm{kg}$ & 81.3 & 81.3 & 81.1 & 81.4 & $80.0^{\mathrm{a}}$ & $82.5^{b}$ & 0.93 & 0.905 & 0.824 & 0.018 \\
\hline Dressing percentage, $\%$ & 77.4 & 78.3 & 77.5 & 78.1 & 77.8 & 77.8 & 0.51 & 0.225 & 0.545 & 0.943 \\
\hline Carcass value index & 108.4 & 108.0 & 108.0 & 108.4 & $105.6^{\mathrm{a}}$ & $110.7^{b}$ & 1.09 & 0.862 & 0.696 & 0.001 \\
\hline Estimated lean yield, $\%$ & 59.6 & 59.2 & 59.4 & 59.4 & $58.3^{\mathrm{a}}$ & $60.5^{b}$ & 0.38 & 0.551 & 0.732 & 0.001 \\
\hline Loin fat depth, mm & 20.1 & 20.9 & 20.6 & 20.6 & $22.9^{a}$ & $18.2^{\mathrm{b}}$ & 0.93 & 0.411 & 0.745 & 0.001 \\
\hline Loin lean depth, mm & 55.1 & 54.6 & 55.4 & 54.4 & $51.9^{\mathrm{a}}$ & $57.8^{\mathrm{b}}$ & 1.27 & 0.611 & 0.452 & 0.001 \\
\hline
\end{tabular}

within main effect, means followed by different letters are significantly different at the $\mathrm{P}$ values indicated 
TABLE 9

Interaction means for the effects of micronization and enzyme supplementation on carcass traits of pigs fed hulless barley-based diets

\begin{tabular}{|c|c|c|c|c|c|c|c|c|}
\hline & \multicolumn{2}{|c|}{ Control barlcy } & \multicolumn{2}{|c|}{ Micronized barley } & \multirow{2}{*}{ S.E.M. } & \multicolumn{3}{|c|}{ P-values' } \\
\hline & - enzyme & + enzyme & - enzyme & + enzyme & & $\mathrm{HxE}$ & $\mathrm{HxS}$ & $E \times S$ \\
\hline Slaughter weight, $\mathrm{kg}$ & 105.3 & 104.6 & 104.0 & 103.6 & 1.10 & 0.97 & 0.69 & 0.53 \\
\hline Hot carcass weight, $\mathrm{kg}$ & 80.8 & 81.7 & 81.5 & 81.0 & 0.93 & 0.58 & 0.75 & 0.27 \\
\hline Dressing percentage, $\%$ & 76.7 & 78.0 & 78.4 & 78.1 & 0.51 & 0.30 & 0.22 & 0.30 \\
\hline Carcass value index & 108.3 & 108.5 & 107.8 & 108.1 & 1.09 & 0.68 & 0.63 & 0.72 \\
\hline Estimated lean yield, $\%$ & 59.5 & 59.6 & 59.2 & 59.2 & 0.38 & 0.66 & 0.62 & 0.45 \\
\hline Loin fat depth, mm & 20.1 & 20.2 & 21.1 & 20.8 & 0.93 & 0.54 & 0.87 & 0.49 \\
\hline Loin lean depth, mm & 55.3 & 54.9 & 55.4 & 53.9 & 1.27 & 0.80 & 0.04 & 0.94 \\
\hline
\end{tabular}

' $\mathrm{H}=$ heat; $\mathrm{E}=$ enzyme; $\mathrm{S}=$ sex

had no effect on the digestibility of dry matter, crude protein or gross energy. The failure of micronization to significantly improve nutrient digestibility contrasts with our earlier experiment (Thacker, 1998) where the faecal digestibility of crude protein was increased by $8.0 \%$ and the digestibility of gross energy increased by $4.4 \%$ as a result of micronization. These results also contrast with the findings of Fernandes et al. (1975) who reported a $6.2 \%$ increase in protein digestibility and a $3.7 \%$ increase in the digestibility of gross energy as a result of micronization of hulled barley when fed to grower pigs. Similarly, Huang et al. (1998) reported a 7.4\% improvement in protein digestibility and a $3.0 \%$ increase in the digestibility of gross energy as a result of micronization of hulless barley diets fed to starter pigs.

Supplementation with $\beta$-glucanase increased the digestibility coefficient for dry matter by $4.2 \%$, crude protein by $9.4 \%$ and gross energy by $7.0 \%$. These increases are of a slightly greater magnitude than we have observed in previous experiments as a result of enzyme supplementation (Thacker et al., 1988, 1992ab; Baas and Thacker, 1995) and are also of a greater magnitude than has been reported by others studying enzyme supplementation for pigs (Graham et al., 1989; Inborr et al., 1993; Jensen et al., 1998). The higher response in the present experiment likely reflects an increase in the solubility of $\beta$-glucan as a result of micronization since this has been demonstrated to occur with other types of heat treatments (Classen et al., 1985). In poultry, an increase in $\beta$-glucan solubilit-y as a result of heat treatment increases its susceptibility to enzymatic attack and increases the effectiveness of enzyme supplementation (Herstad and McNab, 1975).

Consistent with its lack of effect on nutrient digestibility, micronization of barley had no beneficial effect on pig growth rate during any time period measured. The failure of micronization to improve daily gain agrees with our earlier work which showed no beneficial effects of micronization on growth rate (Thacker, 1999). This result contrasts with the findings of Lawrence (1973b) who reported increased 
daily gain in the finisher but not the grower period with micronized barley. However, Fernandes et al. (1975) also noted no improvement in gain for pigs fed micronized vs untreated barley.

In our previous experiment testing the effects of micronization on the nutritive value of barley (Thacker, 1999), feed intake was reduced much more dramatically than in the present experiment although improvements in feed conversion were of a similar magnitude (Thacker, 1999). An improvement in feed efficiency as a result of micronization of barley was noted in only one of two experiments conducted by Lawrence (1973b) while no improvement was observed by Fernandes et al. (1975).

The results of the present experiment showing no improvement in pig performance as a result of $\beta$-glucanase supplementation are consistent with our previous research (Thacker et al. 1988, 1992ab; Baas and Thacker, 1995) and are also consistent with other recent reports by other research groups (Inborr et al., 1993; Officer, 1995; Jensen et al., 1998). The failure of $\beta$-glucanase to improve pig performance is especially disappointing given that several of the experimental parameters were chosen deliberately so as to maximize the potential for a positive response. Hulless barley was used as the foundation for the diets because it has been shown to have a higher $\beta$-glucan content than hulled barley (Bhatty, 1987; Thacker, 1999). In addition, research with poultry has clearly demonstrated a negative effect of heat treatment on the nutritive value of barley which is overcome with enzyme supplementation (Herstad and $\mathrm{McNab}, 1975$ ). The lack of response under these conditions provides little justification for the routine supplementation of pig diets with $\beta$-glucanase.

\section{CONCLUSIONS}

Despite increasing the percentage of gelatinized starch in the diet, no improvement was noted in either nutrient digestibility or pig growth rate as a result of micronization. Supplementation with $\beta$-glucanase reduced diet viscosity and increased the digestibility of dry matter, crude protein and energy. However, pig peformance was not affected. Therefore, it would appear that both micronization and $\beta$-glucanase supplementation are largely ineffective methods of improving the nutritional value of barley for growing-finishing pigs.

\section{REFERENCES}

Association of Official Analytical Chemists, 1980. Official Methods of Analysis. 13th Edition. AOAC, Washington, DC

Baas T.C., Thacker P.A., 1996. Impact of gastric $\mathrm{pH}$ on dietary enzyme activity and survivability in swine fed $\beta$-glucanase supplemented diets. Can. J. Anim. Sci. 76, 245-252 
Bedford M.R., Classen H.L., 1993. An in vitro assay for prediction of broiler intestinal viscosity and growth when fed rye-based diets in the presence of exogenous enzyme. Poultry Sci. 72, 137-143

Bhatty R.S., 1987. Relationship between acid extract viscosity and total soluble and insoluble $\beta$-glucan contents of hulled and hulless barley. Can. J. Plant Sci. 67, 997-1008

Bhatty R.S., 1993. Non-malting uses of barley. In: A.W. MacGregor, R.S. Bhatty (Editors). Barley: Chemistry and Technology. American Association of Cereal Chemists, St Paul, Minnesota, pp. 355417

Bosch M.W., Verstegen M.W.A., 1997. Nutritional effects of expander processing for swine. In: A.F.B. van der Poel (Editor). Expander Processing of Animal Feeds: Chemical, Physical and Nutritional Effects. Wageningen Feed Processing Centre, Wageningen (The Netherlands)

Classen H.L., Campbell G.L., Rossnagel B.G., Bhatty R., Reichert R.D., 1985. Studies on the use of hulless barley in chick diets: Deleterious effect and methods of alleviation. Can. J. Anim. Sci. 65, 725-733

Fadel J.G., Newman C.W., Newman R.K., Graham H., 1988. Effects of extrusion cooking of barley on ileal and fecal digestibilities of dietary components in pigs. Can. J. Anim. Sci. 68, 891-897

Fadel J.G., Newman R.K., Newman C.W., Graham H., 1989. Effects of baking hulless barley on the digestibility of dietary components as measured at the ileum and in the feces in pigs. J. Nutr. 119, 722-726

Fenton T.W., Fenton M., 1979. An improved procedure for the determination of chromic oxide in feed and facces. Can. J. Anim. Sci. 59, 631-634

Fernandes T.H., Hutton K., Smith S.C., 1975. A note on the use of micronized barley for growing pigs. Anim. Prod. 20, 307-310

Graham H., Fadel J.G., Newman C.W., Newman R.K., 1989. Effects of pelleting and beta-glucanase supplementation on the ileal and fecal digestibility of a barley-based diet in the pig. J. Anim. Sci. 67, 1293-1298

Gregory P.C., Rayner D.V., 1986. The role of stomach emptying in short-term control of food intake in pigs. J. Physiol. $378,25 \mathrm{P}$

Hauck B., Rokey G., Smith O., Herbster J., Sunderland R., 1994. Extrusion cooking systems. In: R.R. McEllhiney (Editor). Feed Manufacturing Technology IV. American Fecd Industry Association, Arlington, VA, pp. 131-138

Herstad O., McNab J.M., 1975. The effect of heat treatment and enzyme supplementation on the nutritive value of barley for broilcr chicks. Brit. Poultry Sci. 16, 1-8

Holm J., Bjorck I., Drews A., Asp N.G., 1986. A rapid method for the analysis of starch. Starch / Starke $38,224-226$

Holm J., Bjorck I., 1988. Effects of thermal processing of wheat on starch: II. Enzymic availabililty. J. Cereal Sci. 8, 261-268

Holm J., Lundquist I., Bjorck I., Eliasson A.C., Nils-Georg A., 1988. Degree of starch gelatinization, digestion rate of starch in vitro, and metabolic response in rats. Amer. J. Clin. Nutr. 47, 1010-1016

Holm J., Hagander B., Bjorck I., Eliasson C., Lundquist I., 1989. The effect of various thermal processes on the glycemic response to whole grain wheat products in humans and rats. J. Nutr. $119,1631-1638$

Huang S.X., Sauer W.C., Pickard M., Li S., Hardin R.T., 1998. Effect of micronization on energy, starch and amino acid digestibility in hulless barley for young pigs. Can. J. Anim. Sci. 78, 81-87

Inborr J., Schmitz M., Ahrens F., 1993. Effect of adding fibre and starch degrading enzymes to a barley/wheat based dict on performance and nutrient digestibility in different segments of the small intestine of early weaned pigs. Anim. Feed Sci. Technol. 44, 113-127

Jensen M.S., Bach Knudsen K.E., Inborr I., Jakobsen K., 1998. Effect of $\beta$-glucanase supplementation on pancreatic activity and nutrient digestibility in piglets fed diets based on hulled and hulless barley varieties. Anim. Feed Sci. Technol. 72, 329-345 
Laurinen P., Valaja J., Nasi M., Smids K., 1998. Effect of different expander processing conditions on the nutritive value of barley and wheat by-products in pig dicts. Anim. Feed Sci. Technol. 74, 213.227

Lawrence T.L.J., 1973a. An evaluation of the micronization process for preparing cereals for the growing pig. l. Effects on digestibility and nitrogen retention. Anim. Prod. 16, 99-107

Lawrence T.L.J., 1973b. An evaluation of the micronization process for preparing cereals for the growing pig. 2. Effects on growth rate, food conversion efficiency and carcass characteristics. Anim. Prod. 16, 109-116

Leeds A.R., Bolster N.R., Andrews R., Truswell A.S., 1979. Meal viscosity, gastric emptying and glucose absorption in the rat. Proc. Nutr. Soc. 38, 44A

Nasi M., 1992. Effects of grinding, pelleting and expanding on the nutritive value of barley in pig diets. Agric. Sci. Finland 1, 461-469

National Academy of Sciences; National Research Council, 1988. Nutrient Requirements of Domestic Animals. No. 2. Nutrient Requirements of Swine. 9th Edition. NAS-NRC, Washington, DC

Officer D.I., 1995. Effect of multi-enzyme supplements on the growth performance of piglets during the pre- and post-weaning periods. Anim. Feed Sci. Technol. 56, 55-65

Saskatchewan Pork Producers Marketing Board, 1995. Saskathewan Grading Table (March 6, 1995)

Statistical Analysis System Institute., Inc., 1985. SAS Users Guide, Version 5, SAS Institute Inc., Cary, NC

Thacker P.A., Campbell G.L., GrootWassink J.W.D., 1988. The effect of beta-glucanase supplementation on the performance of pigs fed hulless barley. Nutr. Rep. Int. 38, 91-99

Thacker P.A., Campbell G.L., GrootWassink J.W.D., 1992a. Effect of salinomycin and enzyme supplementation on nutrient digestibility and performance of pigs fed barley-or rye-based diets. Can. J. Anim. Sci. 72, 117-125

Thacker P.A., Campbell G.L., GrootWassink J.W.D., 1992b. Effect of organic acids and enzyme supplementation on the performance of pigs fed barley-based diets. Can. J. Anim. Sci. 72, 395-402

Thacker P.A., 1999. Effect of micronization on the performance of growing/finishing pigs fed diets based on hulled and hulless barley. Anim. Feed Sci. Technol. 79, 29-41

\section{STRESZCZENIE}

Wyniki produkcyjne w okresie wzrostu i tuczu świń żywionych dawkami $z$ udzialem ziarna jęczmienia nagiego, zwyklego lub po jego mikronizacji, bez dodatku lub z dodatkiem $\beta$-glukanazy

W doświadczeniu, o układzie czynnikowym, przeprowadzonym na 80 świniach-mieszańcach badano wpływ mikronizacji oraz dodatku $\beta$-glukanazy na wyniki produkcyjne świń żywionych dawkami, w których podstawową paszą był jęczmień nagi. Mikronizacja jęczmienia zwiększała zawartość zżelatynizowanej skrobi w diccie, a dodatek enzymu obniżał lepkość dawki. Strawność suchej masy, białka ogólnego i energii zwiększała się pod wpływem dodatku enzymu, natomiast mikronizacja ziarna nie miała na to wpływu, podobnic jak i na tempo wzrostu świń. Pobranic paszy było nieco zmniejszone, w następstwie tego lepsze było jej wykorzystanie. Dodatek enzymu nie wpływal na tempo wzrostu, lecz istotnic poprawiał wykorzystanie paszy w okresie tuczu. Tak dodatek enzymu, jak i mikronizacja ziarna nie wpłynęły na jakość tuszy. 